\title{
ANALISIS KESULITAN BELAJAR SISWA PADA MATERI SISTEM EKSKRESI MANUSIA
}

\author{
Anggita Simorangkir*, Martina A. Napitupulu, Tonggo Sinaga \\ Program Studi Pendidikan Biologi, FMIPA, Universitas Negeri Medan, Medan \\ Jl. Willem Iskandar Psr. V Medan Estate, Medan, Indonesia, 20221 \\ *Korespondensi Author: gitasimorangkir14@gmail.com
}

\section{INFO ARTIKEL}

Histori Artikel

Received 7 November 2018

Revised 26 Maret 2020

Accepted 26 Maret 2020

Published 2 April 2020

Keywords:

cognitive aspects, human excretory systems, learning difficulty

\begin{abstract}
ABSTRAK
This research aims to know the student's learning difficulty on the material of Human Excretion System from cognitive aspects and indicator aspects and factors causing students learning difficulties on the Human Excretion System on class XI IPA SMA Swasta Teladan Medan Academic Year 2017/2018. The population of this research is all students of class XI IPA which amounts to 118 students. The sample was taken by purposive sampling which amounts to 45 students. The instruments used to obtain data were tested student learning outcomes in the material of the Human Excretion System and learning difficulties questionnaire. The results of the research showed that students were categorized as incomplete. The percentage of student learning difficulties in cognitive aspect for C1, C2, C3, C4, C5, and C6 is $40,11 \%$ (medium), 37,82\% (low), 41,69\% (medium), 53,39\% (medium), 49,15\% (medium), dan $60,45 \%$ (high). The percentage of student learning difficulties based on the learning indicators is mentioned the meaning of the excretion system and its organs in the amount of $37,29 \%$ (low), identify the structure and function of the kidney in the amount of $35,59 \%$ (low), describe the structure of the nephron and explain the process of human urine formation in the amount of $42,91 \%$ (medium), identify the structure and function of the liver in the amount of $42,94 \%$ (medium), identify the structure and function of the lung in the amount of $47,46 \%$ (medium), identify the structure and function of the skin in the amount of $48,31 \%$ (medium), and determine abnormalities or diseases in human excretory organs in the amount of $55,37 \%$ (medium). Difficulties in the indicators of structure and function of the kidney and the process of formation of urine are categorized as inhibitory. Indicators of the understanding of the excretion system and its organs, the structure and function of the lung, the structure and function of the liver, abnormalities in the human excretory system, and the learning system in the material of the human excretory system are quite inhibiting categories. While indicators of the structure and function of the skin are categorized as not inhibiting.
\end{abstract}

Copyright (c) 2019 Universitas Negeri Medan. Artikel Open Access dibawah lisensi CCBY-4.0 (https://creativecommons.org/licenses/by/4.0)

\section{How To Cite:}

Simorangkir, A., \& Napitupulu, M. A. (2020). Analisis Kesulitan Belajar Siswa Pada Materi Sistem Ekskresi Manusia. Jurnal Pelita Pendidikan, 8(1), 001-011 


\section{PENDAHULUAN}

Belajar merupakan proses manusia untuk mencapai berbagai macam kompetensi, keterampilan, dan sikap. Belajar dimulai sejak manusia lahir sampai akhir hayat. Kemampuan manusia untuk belajar merupakan karakteristik penting yang membedakan manusia dengan makhluk hidup lainnya. Belajar dapat membawa perubahan, baik perubahan pengetahuan, sikap, maupun keterampilan. Dengan perubahan tersebut, tentunya juga akan membantu memecahkan permasalahan dan bisa menyesuaikan diri dengan lingkungannya (Baharuddin dan Esa, 2015).

Di dalam sebuah proses belajar, guru memberikan materi pembelajaran kepada siswa supaya dapat dipahami dan dimengerti oleh siswa tersebut. Tujuan sebuah proses pembelajaran adalah seseorang yang belajar mampu mengetahui dan memahami maksud dari data, informasi, dan pengetahuan yang diperoleh dari sumber terpercaya. Kenyataannya, seringkali siswa tidak mampu mencapai tujuan belajarnya atau tidak memperoleh tingkah laku sebagaimana yang diharapkan. Hal itu menunjukkan bahwa siswa mengalami kesulitan dalam belajar sehingga tidak mampu mencapai hasil belajar yang memuaskan (Ristiyani dan Evi, 2016).

Biologi sebagai salah satu mata pelajaran yang kompleks karena di dalamnya membahas tentang seluruh makhluk hidup yang ada di Bumi. Dalam pelaksanaan pembelajaran biologi, dituntut berbagai jenis keterampilan proses seperti halnya keterampilan mengamati, mengukur, menggunakan alat, melakukan eksperimen, serta mengkomunikasikan hasil eksperimen tersebut baik secara lisan maupun tulisan. Pembelajaran yang demikian diharapkan akan menghasilkan kemampuan seseorang yang meliputi kemampuan kognitif, afektif, dan psikomotorik.

Mata pelajaran biologi memiliki karakteristik yang demikian disebutkan di atas menjadi tantangan bagi para siswa dalam hal belajar dan juga bagi guru dalam hal proses mengajar. Tidak jarang karakteristik biologi yang khas tersebut menjadikan para siswa mengalami kesulitan dalam memahami mata pelajaran biologi (Hasibuan, 2013).
Kesulitan siswa dalam belajar biologi telah dipelajari oleh beberapa peneliti di seluruh dunia. Banyak konsep atau topik dalam biologi, seperti pengangkutan air pada tanaman, sintesis protein, respirasi dan fotosintesis, pertukaran gas, energi sel, mitosis dan meiosis, organ tubuh, proses fisiologis, regulasi hormonal, transportasi oksigen, genetika, genetika Mendel, rekayasa genetik, dan sistem saraf pusat dapat dianggap sulit dipelajari oleh siswa sekolah menengah. Kesulitan siswa dengan banyak topik biologi, mendorong peneliti untuk menyelidiki mengapa siswa mengalami kesulitan tersebut dan bagaimana mengatasi kesulitan tersebut.ada berbagai alasan mengapa siswa mengalami kesulitan dalam mempelajari konsep biologi. Sifat sains itu sendiri dan metode pengajarannya termasuk di antara alasan kesulitan dalam belajar sains, tingkat organisasi biologi dan tingkat abstrak konsep membuat belajar biologi menjadi sulit. Kurikulum biologi yang kelebihan muatan, sifat abstrak dan interdisipliner konsep biologi, dan kesulitan mendapatkan buku teks adalah faktor lain yang menghambat siswa belajar biologi secara efektif. Dalam penelitiannya, Cimer (2012) mengungkapkan bahwa dari 207 siswa terdapat 177 siswa menyatakan lima topik biologi paling sulit dari 38 topik biologi yang tertera dalam instrumen penelitian. Kelima topik itu adalah topik siklus, sistem endikrin dan hormon, respirasi aerobik, pembelahan sel, gen dan kromosom.

Berdasarkan hasil wawancara dengan salah satu guru biologi di SMA Swasta Teladan Medan, yang bernama Helmiati Surbakti, S.Pd (Komunikasi Pribadi), diketahui sistem ekskresi merupakan salah satu materi pada mata pelajaran biologi yang sulit untuk dikuasai oleh siswa yaitu ditandai dengan masih banyak siswa yang tidak mencapai nilai KKM, yaitu 75 . Terdapat $30 \%$ siswa yang memperoleh nilai di bawah KKM $(<75)$ pada materi system ekskresi manusia di kelas XI IPA 2, dengan jumlah 44 orang siswa. Beliau mengatakan bahwa para siswa yang tidak mencapai nilai KKM karena kurangnya minat siswa untuk mengulang materi pelajaran ketika akan diadakan tes.

Dari hasil observasi, siswa berpendapat bahwa materi sistem ekskresi manusia merupakan materi pelajaran yang kurang disukai bahkan cenderung membosankan karena proses belajar yang menuntut mereka untuk menghafal terminologi maupun bahasa Latin pada pengenalan organ yang 
terlibat dalam proses pengeluaran manusia, sulit membedakan proses pengeluaran pada manusia, serta pemahaman tentang proses pembentukan urin yang sulit dimengerti.

\section{METODE PENELITIAN}

Penelitian ini dilakukan di SMA Swasta Teladan Medan dan penelitian dilaksanakan pada Januari sampai Agustus 2018 Semester II Tahun Pembelajaran 2017/2018. Populasi penelitian ini adalah siswa kelas XI IPA SMA Swasta Teladan Medan Tahun Pembelajaran 2017/2018 yang terdiri dari XI IPA 1, XI IPA 2, dan XI IPA 3. Pengambilan sampel pada penelitian ini dilakukan dengan cara Purposive sampling. Yang menjadi sampel penelitian ini adalah 15 orang siswa dari masingmasing kelas populasi yang memperoleh nilai terendah di bawah KKM (<75). Instrumen yang digunakan dalam pengumpulan data adalah tes hasil belajar dan angket. Jenis penelitian ini adalah penelitian deskriptif kuantitatif.

\section{HASIL DAN PEMBAHASAN}

\section{Hasil Belajar Siswa}

Penelitian ini menghasilkan data yang menunjukkan hasil belajar siswa dan tingkat kesulitan belajar siswa pada materi sistem ekskresi manusia. Data hasil belajar siswa ditinjau dari aspek kognitif, aspek indikator, dan tingkat kesulitan materi sistem ekskresi manusia. Pada Tabel 1 menjelaskan tentang nilai rata-rata yang diperoleh siswa kelas XI IPA SMA Swasta Teladan Medan melalui tes.
Tabel 1. Distribusi Frekuensi Hasil Belajar Siswa

\begin{tabular}{ccc}
\hline No & Nilai $(\mathbf{X})$ & Jumlah Sampel \\
\hline 1 & 33,33 & 1 \\
2 & 36,67 & 10 \\
3 & 40 & 6 \\
4 & 43,33 & 32 \\
5 & 46,67 & 25 \\
6 & 50 & 2 \\
7 & 53,33 & 2 \\
8 & 56,67 & 1 \\
9 & 60 & 1 \\
10 & 66,67 & 1 \\
\hline & Jumlah & 81
\end{tabular}

Berdasarkan Tabel 1 di atas diketahui terdapat siswa yang tidak tuntas pada materi Sistem Ekskresi Manusia yaitu siswa memperoleh nilai tes hasil belajar di bawah KKM $(<75)$ sebanyak 81 orang siswa atau 68,64\% dari jumlah keseluruhan yaitu 118 siswa dengan nilai rata-rata 44,239. Hal ini menunjukkan bahwa siswa kelas XI IPA SMA Swasta Teladan Medan Tahun Pembelajaran 2017/2018 mengalami kesulitan belajar pada materi Sistem Ekskresi Manusia. Pada penelitian ini, kesulitan belajar siswa pada materi Sistem Ekskresi Manusia meliputi dua aspek, yaitu aspek kognitif dan aspek indikator pembelajaran.

\section{Aspek Kognitif}

Aspek kognitif merupakan aspek yang berhubungan dengan kemampuan berpikir siswa dalam mengetahui atau memahami materi Sistem Ekskresi Manusia. Tingkat kemampuan kognitif siswa dapat dilihat dari segi kemampuan siswa dalam mengerjakan soal materi Sistem Ekskresi Manusia. Menurut Bloom, terdapat enam kategori aspek kognitif dari yang sederhana sampai dengan yang lebih kompleks, yaitu C1 (mengingat), C2 (memahami), C3 (menerapkan), C4 (menganalisis), C5 (mengevaluasi), dan C6 (mensintesis).

Tabel 2. Distribusi Kesulitan Belajar Siswa Tiap Aspek Kognitif

\begin{tabular}{lllcccc}
\hline No & Aspek Kognitif & $\begin{array}{c}\text { Skor } \\
\text { Ideal }\end{array}$ & $\begin{array}{c}\text { Skor } \\
\text { Capaian }\end{array}$ & PPS (\%) & Kesulitan Belajar (\%) & Kategori \\
\hline 1 & C1 (Pengetahuan) & 486 & 212 & 43,62 & 56,38 & Sedang \\
2 & C2 (Pemahaman) & 648 & 322 & 49,69 & 50,31 & Sedang \\
3 & C3 (Aplikasi) & 405 & 208 & 51,36 & 48,64 & Sedang \\
4 & C4 (Analisis) & 567 & 229 & 40,39 & 59,61 & Sedang \\
5 & C5 (Evaluasi) & 243 & 71 & 29,22 & 70,78 & Tinggi \\
6 & C6 (Sintesis) & 81 & 33 & 40,74 & 59,26 & Sedang \\
\hline
\end{tabular}


Berdasarkan Tabel 2 di atas dapat diketahui bahwa tingkat kesulitan belajar siswa pada materi Sistem Ekskresi Manusia di kelas XI IPA SMA Swasta Teladan Medan ditinjau dari aspek kognitif taksonomi Bloom adalah sebagai berikut persentase kesulitan belajar siswa yang termasuk dalam kategori kesulitan tinggi yaitu C5 (Evaluasi) sebesar 70,78\%. Sedangkan persentase kesulitan belajar siswa yang termasuk dalam kategori kesulitan sedang yaitu C1 (Pengetahuan) sebesar 56,38\%, C2 (Pemahaman) sebesar 50,31\%, C3 (Aplikasi) sebesar 48,64\%, C4 (Analisis) sebesar $59,61 \%$, dan C6 (Sintesis) sebesar 59,26\%.

Aspek kognitif meliputi kemampuan siswa dalam menyatakan kembali konsep atau prinsip yang telah dipelajari, yang berkaitan dengan kemampuan berpikir, kemampuan dalam memperoleh pengetahuan, pemahaman, konseptualisasi, penentuan, dan penalaran. Tujuan pengukuran aspek kognitif adalah untuk mendapatkan informasi yang akurat mengenai tingkat pencapaian tujuan pembelajaran siswa pada tingkat hapalan pemahaman, penerapan, analisis, sintesis dan evaluasi. Aspek kognitif terdiri dari enam jenjang tingkat berpikir mulai dari yang terendah (Low Order Thinking) hingga yang tertinggi (High Order Thinking) yang disingkat dengan $\mathrm{C}$ (Cognitive). Setelah mendapat hasil tes maka nilai dari masing-masing aspek kognitif akan dijelaskan sebagai berikut.

\section{C1 (Pengetahuan)}

Pada aspek kognitif ini siswa diharapkan mampu untuk mengingat kembali (recall) apa yang telah dipelajari sebelumnya baik oleh guru maupun sumber belajar lainnya. Siswa diharapkan mampu menyampaikan informasi/pengetahuan sederhana secara verbal atau tulisan. Aspek kognitif ini memiliki sifat ingatan semata, tanpa ada interpretasi atau manipulasi dari siswa sebab apa yang diingat dan disampaikan adalah data dan fakta.

Pada tingkatan aspek kognitif ini sering digunakan kata kerja operasional mengidentifikasi, menyebutkan, menuliskan, menjodohkan, membaca, menghafal, memilih. Untuk aspek kognitif C1 terdapat 6 soal yang tersebar pada indikator 1 (2 soal), indikator 3 (2 soal), dan indikator 6 ( 2 soal). Dari hasil tes ditemukan bahwa siswa kelas XI IPA SMA Swasta Teladan Medan mengalami kesulitan belajar pada aspek kognitif ini dengan persentase $40,11 \%$ yang termasuk dalam kategori kesulitan belajar sedang, karena lebih dari setengah jumlah siswa keseluruhan mampu menjawab soal dengan benar.

Untuk soal pada aspek kognitif C1 telah menggunakan kata kerja operasional seperti mengidentifikasi, menyebutkan, menuliskan, menjodohkan, membaca, menghafal, memilih sehingga menjadi aspek yang cukup mudah bagi siswa. Oleh sebab itu dapat disimpulkan bahwa siswa tidak mengalami kesulitan belajar yang tinggi melalui tes yang diberikan. Hal ini disebabkan oleh proporsi tes yang sudah sesuai dengan seharusnya.

\section{C2 (Pemahaman)}

Pada aspek kognitif ini, siswa diharapkan mampu membangun makna atau pengertian berdasarkan pengetahuan awal yang dimiliki, atau mengintegrasikan pengetahuan yang baru ke dalam skema yang telah ada dalam pemikiran siswa. Selain itu terdapat kemampuan lain yang diharapkan pada aspek kognitif ini, yaitu 1. Translasi (kemampuan mengubah simbol dari satu bentuk ke bentuk lain) 2. Interpretasi (kemampuan menjelaskan materi) 3. Ekstrapolasi (kemampuan memperluas arti). Pada aspek ini siswa mampu menjawab pertanyaan dengan kata-katanya sendiri dan dengan memberikan contoh baik prinsip maupun konsep.

Kata kerja operasional yang biasanya dipakai dalam aspek kognitif ini adalah menafsirkan, memberikan contoh, mengklasifikasikan, meringkas, membandingkan, menjelaskan, dan membandingkan. Pada aspek kognitif ini terdapat 8 soal yang tersebar pada indikator 2 (1 soal), indikator 3 (4 soal), indikator 5 (2 soal), dan indikator 6 (1 soal). Pada aspek ini tingkat kesulitan belajar siswa kelas XI IPA SMA Swasta Teladan Medan tergolong kategori rendah, yaitu dengan persentase $37,82 \%$. Artinya lebih dari setengah jumlah siswa seluruhnya mampu menjawab soal dengan benar.

\section{C3 (Aplikasi)}

Pada aspek ini, siswa dituntut untuk menerapkan informasi di dalam berbagai situasi. Menurut Kwartolo (2012), untuk dapat dikategorikan sebagai kegiatan mengaplikasikan, masalah harus unik. Sehingga siswa harus mampu menerapkan konsep dan prinsip yang ia miliki pada 
situasi baru yang belum pernah dialami sebelumnya.

Kata kerja operasional yang dipakai pada aspek kognitif ini adalah mengubah, menghitung, mendemostrasikan, menemukan, memanipulasi, memodifikasi, mengoperasikan, meramalkan, menyiapkan, menghasilkan, menghubungkan, menunjukkan, memecahkan, menggunakan. Jumlah soal pada aspek kognitif ini adalah 5 soal yang tersebar pada indikator 4 ( 3 soal) dan indikator 5 (2 soal). Pada aspek ini tingkat kesulitan belajar siswa kelas XI IPA SMA Swasta Teladan Medan tergolong sedang dengan persentase $41,69 \%$.

\section{C4 (Analisis)}

Pada aspek kognitif ini siswa diharapkan mampu menguraikan suatu materi yang diperolehnya baik secara langsung maupun tidak langsung menjadi komponen yang lebih jelas. Kategori analisis dibedakan menjadi tiga, yaitu: (1) analisis elemen yaitu analisis elemen-elemen dari suatu komunikasi; (2) analisis hubungan yaitu analisis koneksi dan interaksi antara elemenelemen dan bagian-bagian dari suatu komunikasi; dan (3) analisis prinsip pengorganisasian yaitu analisis susunan dan struktur yang membentuk suatu komunikasi. Di jenjang ini, peserta didik diminta untuk menguraikan informasi ke dalam beberapa bagian menemukan asumsi, dan membedakan pendapat dan fakta serta menemukan hubungan sebab akibat.

Kata kerja operasional yang dipakai dalam aspek kognitif ini adalah membedakan, menyamakan, mengelompokkan, mengintegrasikan, menyusun ulang, menguraikan, mengorganisir, menyeleksi, menghubungkan, mempertentangkan. Beedasarkan hasil tes diketahui bahwa siswa kelas XI IPA SMA Swasta Teladan Medan mengalami kesulitan belajar pada tingkatan sedang dengan persentase $53,39 \%$ yang artinya lebih dari setengah jumlah seluruh siswa menjawab salah pada soal pada aspek kognitif ini. Jumlah soal pada aspek ini adalah 7 soal yang tersebar pada indikator 3 (3 soal), indikator 6 (2 soal), dan indikator 7 ( 2 soal). Kata kerja operasional yang digunakan dalam soal tersebut adalah mengidentifikasi, mengilustrasikan, dan menyimpulkan. Pemilihan kata kerja operasional yang tepat dapat membantu siswa dalam menjawab soal dengan benar.

\section{C5 (Evaluasi)}

Aspek kognitif ini merujuk pada kemampuan siswa dalam memberikan penilaian terhadap sesuatu yang dievaluasi. Ini berarti siswa dengan sendirinya telah memiliki berbagai bahan pertimbangan yang diperlukan untuk memberikan nilai. Evaluasi dapat dilakukan dallam bentuk kuantitatif dan kualitatif yang didasarkan atas kriteria internal atau eksternal (Kwartolo, 2012).

Kata kerja operasional yang digunakan pada aspek kognitif ini adalah menguji, menilai mengkritik, memprediksi, membenarkan, menyalahkan, menyusun hipotesis, memperbandingkan, mengevaluasi, menyimpulkan. Jumlah soal pada aspek ini adalah 3 soal yang tersebar pada indikator 3 (1 soal), indikator 5 (1 soal), dan indikator 7 (1 soal). Berdasarkan hasil tes diketahui bahwa siswa kelas XI IPA SMA Swasta Teladan Medan mengalami kesulitan belajar sebesar 60,45\% yang termasuk ketegori tinggi. Persentase tersebut merupakan persentase kesulitan belajar dengan nilai yang paling tinggi dibandingkan dengan persentase kesulitan belajar aspek kognitif lainnya. Pada soal dalam tingkatan ini siswa diminta untuk menafsirkan, menyimpulkan, dan menilai kemungkinan yang akan terjadi dalam suatu permasalahan. Hal tersebut membuat siswa mengalami kesulitan dalam mengevaluasi dan membuktikan sesuai dengan pengetahuan yang ia miliki.

\section{C6 (Sintesis)}

Aspek kognitif ini merujuk pada kemampuan siswa dalam memadukan berbagai macam informasi dan mengembangkannya sehingga menjadi sesuatu bentuk yang baru. Sintesis bersangkutan dengan penyusunan bagian-bagian atau unsur-unsur sehingga membentuk kesatuan yang sebelumnya tidak tampak jelas menjadi jelas. Aspek ini juga meliputi menciptakan komunikasi yang unik, menciptakan rencana, dan menciptakan rangkaian hubungan abstrak. Pada aspek kognitif ini siswa dituntut mampu menghasilkan suatu hipotesis atau teorinya sendiri yang didasarkan pada pengetahuan yang diperolehnya.

Kata kerja operasional yang digunakan dalam aspek ini adalah merancang, membangun, mengarang, merencanakan, memproduksi, 
menemukan, membaharui, menyempurnakan, memperkuat, menggubah. Aspek ini termasuk sebagai salah satu aspek kognitif yang tergolong sulit dibandingkan yang lainnya. Dalam menyelesaikan soal pada kategori ini siswa harus benar-benar kritis dan teliti. Jumlah soal pada aspek ini adalah 1 soal yang hanya terdapat pada indikator 3. Berdasarkan hasil tes diketahui bahwa siswa mengalami kesulitan belajar sebesar 49,15\% dengan kategori sedang.

\section{Aspek Indikator Pembelajaran}

Dari hasil tes belajar siswa yang diperoleh dilakukan juga analisis hasil belajar siswa pada materi Sistem Ekskresi Manusia berdasarkan indikator pembelajaran. Aspek indikator pembelajaran Sistem Ekskresi menjadi pedoman dalam merancang, melaksanakan, serta mengevaluasi hasil belajar siswa. Rancangan serta evaluasi tersebut akan memberikan acuan dalam menentukan hasil belajar siswa. Aspek indikator pembelajaran materi Sistem Ekskresi Manusia, ditemukan dari silabus pembelajaran materi pokok Sistem Ekskresi Manusia. Pada silabus pembelajaran tersebut meliputi: (1) Menyebutkan pengertian sistem ekskresi serta organnya; (2) Mengidentifikasi struktur dan fungsi ginjal sebagai organ ekskresi manusia; (3) Mendeskripsikan struktur nefron dan menjelaskan proses pembentukan urin pada manusia; Mengidentifikasi struktur dan fungsi hati sebagai organ ekskresi manusia; (5) Mengidentifikasi struktur dan fungsi paru-paru sebagai organ ekskresi manusia; (6) Mengidentifikasi struktur dan fungsi kulit sebagai organ ekskresi manusia; dan (7) Menentukan kelainan atau penyakit pada organ ekskresi pada manusia. Tabel 3 akan dijelaskan kategori kesulitan belajar siswa dari aspek indikator pembelajaran.

Berdasarkan Tabel 3, persentase kesulitan belajar siswa ditinjau dari aspek indikator pembelajaran tergolong pada kategori rendah dan sedang. Indikator pembelajaran yang tergolong kategori sedang adalah indikator (1) Menyebutkan pengertian sistem ekskresi serta organnya dengan persentase $54,32 \%$, indikator (2) Mengidentifikasi struktur dan fungsi ginjal sebagai organ ekskresi manusia dengan persentase $48,15 \%$, indikator (3) Mendeskripsikan struktur nefron dan menjelaskan proses pembentukan urin pada manusia dengan persentase $54,32 \%$, indikator (4) Mengidentifikasi struktur dan fungsi hati sebagai organ ekskresi manusia dengan persentase $47,33 \%$, indikator (5) Mengidentifikasi struktur dan fungsi paru-paru sebagai organ ekskresi manusia dengan persentase $58,27 \%$, indikator (6) Mengidentifikasi struktur dan fungsi kulit sebagai organ ekskresi manusia dengan persentase 57,04\%. Sedangkan indikator (7) Menentukan kelainan atau penyakit pada organ ekskresi pada manusia tergolong kategori tinggi dengan persentase $66,67 \%$.

Tabel 3. Distribusi Kesulitan Belajar Siswa Tiap Aspek Indikator Pembelajaran

\begin{tabular}{|c|c|c|c|c|c|c|}
\hline No & Indikator & $\begin{array}{l}\text { Skor } \\
\text { Ideal }\end{array}$ & $\begin{array}{c}\text { Skor } \\
\text { Capaian }\end{array}$ & $\begin{array}{l}\text { PPS } \\
(\%)\end{array}$ & $\begin{array}{c}\text { Kesulitan } \\
\text { Belajar (\%) }\end{array}$ & Kategori \\
\hline 1 & $\begin{array}{l}\text { Menyebutkan pengertian sistem } \\
\text { ekskresi serta organnya. }\end{array}$ & 81 & 74 & 45,68 & 54,32 & Sedang \\
\hline 2 & $\begin{array}{l}\text { Mengidentifikasi struktur dan fungsi } \\
\text { ginjal sebagai } \\
\text { organ ekskresi manusia. }\end{array}$ & 162 & 42 & 51,85 & 48,15 & Sedang \\
\hline 3 & $\begin{array}{l}\text { Mendeskripsikan struktur nefron dan } \\
\text { menjelaskan proses pembentukan } \\
\text { urin pada manusia. }\end{array}$ & 891 & 407 & 45,68 & 54,32 & Sedang \\
\hline 4 & $\begin{array}{l}\text { Mengidentifikasi struktur dan fungsi } \\
\text { hati sebagai organ ekskresi manusia. }\end{array}$ & 243 & 128 & 52,67 & 47,33 & Sedang \\
\hline 5 & $\begin{array}{l}\text { Mengidentifikasi struktur dan fungsi } \\
\text { paru-paru sebagai organ ekskresi } \\
\text { manusia. }\end{array}$ & 405 & 169 & 41,73 & 58,27 & Sedang \\
\hline $\begin{array}{l}6 \\
7\end{array}$ & $\begin{array}{l}\text { Mengidentifikasi struktur dan fungsi } \\
\text { kulit sebagai organ ekskresi manusia. } \\
\text { Menentukan kelainan atau penyakit }\end{array}$ & 405 & 174 & $\begin{array}{l}42,96 \\
33,33\end{array}$ & 57,04 & Sedang \\
\hline & pada organ ekskresi pada manusia. & 243 & 81 & & 66,67 & Tinggi \\
\hline
\end{tabular}




\section{Menyebutkan Pengertian Sistem Ekskresi serta Organnya}

Pada indikator pembelajaran ini, siswa kelas XI IPA SMA Swasta Teladan Medan mengalami kesulitan yang tergolong rendah dengan persentase $37,29 \%$. Berdasarkan persentase tersebut dapat diketahui bahwa lebih dari setengah jumlah siswa tidak mengalami kesulitan dalam menjawab soal pada indikator pembelajaran ini. Jumlah soal pada indikator pembelajaran ini adalah 2 soal yang keduanya tergolong pada soal C1 (Pengetahuan). Materi pada indikator ini mencakup pengertian sistem ekskresi manusia dan organ tubuh yang berfungsi sebagai organ ekskresi.

Berdasarkan hasil yang telah diperoleh dapat diketahui bahwa siswa tidak mengalami kesulitan dalam menjawab soal pada indikator ini. Hal ini disebabkan karakter soal yang tergolong mudah dengan tingkat kognitif C1 yang hanya mengandalkan kemampuan siswa dalam mengingat kembali informasi yang telah diterima sebelumnya.

\section{Mengidentifikasi Struktur dan Fungsi Ginjal sebagai Organ Ekskresi Manusia \\ Pada indikator pembelajaran ini, siswa kelas XI}

IPA SMA Swasta Teladan Medan mengalami kesulitan belajar yang tergolong rendah dengan persentase siswa yang mengalami kesulitan belajar sebesar 35,59\%. Berdasarkan pesentase tersebut dapat diketahui bahwa lebih dari setengah jumlah siswa tidak mengalami kesulitan dan mampu menjawab soal pada indikator ini dengan benar. Jumlah soal pada indikator ini adalah 1 soal yang tergolong pada aspek kognitif C2 (Pemahaman). Materi pada indikator ini berkaitan dengan struktur dan fungsi ginjal sebagai organ ekskresi manusia. Banyaknya siswa yang tidak mengalami kesulitan dalam menjawab soal pada indikator pembelajaran ini disebabkan oleh karakter soal yang tergolong cukup mudah tanpa menuntut siswa dalam berpikir lebih.

\section{Mendeskripsikan Struktur Nefron dan Menjelaskan Proses Pembentukan Urin pada Manusia}

Pada indikator pembelajaran ini, siswa kelas XI IPA SMA Swasta Teladan Medan mengalami kesulitan belajar yang tergolong sedang dengan persentase siswa yang mengalami kesulitan belajar sebesar 42,91\%. Berdasarkan persentase tersebut diketahui bahwa hampir setengah siswa mengalami kesulitan belajar. Jumlah soal pada indikator pembelajaran ini adalah 11 soal yang tersebar pada aspek kognitif C1 (2 soal), C2 (4 soal), C4 (3 soal), C5 (1 soal), dan C6 (1 soal). Materi pada indikator pembelajaran 3 adalah struktur nefron dan proses pembentukan urin pada manusia. Kesulitan tersebut terjadi karena materi tersebut bersifat abstrak, pembagian struktur nefron, dan adanya urutan dalam proses pembentukan urin yang belum dimengerti oleh siswa.

Berdasarkan hasil yang diperoleh dapat diketahui bahwa soal untuk indikator pembelajaran 3 memiliki kesulitan sedang. Dalam menjawab soal siswa dituntut untuk mengetahui, memahami, menganalisis, mensintesis, dan mengevaluasi informasi atau pengetahuan yang diterima sebelumnya. Hal tersebut menjadi alasan utama yang membuat siswa mengalami kesulitan belajar pada indikator mendeskripsikan struktur nefron dan menjelaskan proses pembentukan urin.

\section{Mengidentifikasi Struktur dan Fungsi Hati sebagai Organ Ekskresi Manusia}

Pada indikator pembelajaran ini siswa kelas XI IPA SMA Swasta Teladan Medan mengalami kesulitan belajar yang tergolong sedang dengan persentase $42,94 \%$. Berdasarkan persentase tersebut dapat diketahui bahwa hampir setangah dari jumlah siswa seluruhnya mengalami kesulitan belajar pada indikator ini. Jumlah soal pada indikator pembelajaran ini adalah 3 soal yang ketiganya terdapat pada aspek kognitif C3 (Aplikasi). Materi pada indikator pembelajaran ini adalah struktur dan fungsi hati sebagai organ ekskresi manusia.

Untuk menghadapi kesulitan belajar yang dialami oleh siswa, guru diharapkan mampu untuk menerapkan model pembelajaran yang sesuai dan dapat membantu siswa dalam memahami materi pelajaran dengan baik. Kaberi (2016) menyatakan dalam penelitiannya bahwa penggunaan model pembelajaran inkuiri terbimbing dapat meningkatkan hasil belajar siswa pada materi Sistem Ekskresi Manusia. Selain itu, model pembelajaran ini juga meningkatkan aktivitas siswa karena pada model pembelajaran ini siswa itu sendiri yang menentukan inti dari pelajaran yang diterimanya. 


\section{Mengidentifikasi Struktur dan Fungsi Paru-paru sebagai Organ Ekskresi Manusia}

Pada indkator pembelajaran ini siswa kelas XI

IPA SMA Swasta Teladan Medan mengalami kesulitan belajar yang tergolong sedang dengan persentase $47,46 \%$. Berdasarkan persentase tersebut dapat diketahui bahwa hampir setangah dari jumlah siswa seluruhnya mengalami kesulitan belajar pada indikator ini. Jumlah soal pada indikator pembelajaran ini adalah 5 soal yang tersebar pada aspek kognitif C2 (2 soal), C3 (2 soal), dan C5 (1 soal). Materi pada indikator pembelajaran ini adalah struktur dan fungsi paru-paru sebagai organ ekskresi manusia.

\section{Mengidentifikasi Struktur dan Fungsi Kulit sebagai Organ Ekskresi Manusia}

Pada indikator pembelajaran ini siswa kelas XI IPA SMA Swasta Teladan Medan mengalami kesulitan belajar yang tergolong sedang dengan persentase 48,31\%. Berdasarkan persentase tersebut dapat diketahui bahwa hampir setangah dari jumlah siswa seluruhnya mengalami kesulitan belajar pada indikator ini. Jumlah soal pada indikator pembelajaran ini adalah 5 soal yang tersebar pada aspek kognitif C1 (2 soal), C2 (1 soal), dan C4 ( 2 soal). Materi pada indikator pembelajaran ini adalah struktur dan fungsi kulit sebagai organ ekskresi manusia.

\section{Menentukan Kelainan atau Penyakit pada Organ Ekskresi Manusia}

Pada indikator pembelajaran ini siswa kelas XI IPA SMA Swasta Teladan Medan mengalami kesulitan belajar yang tergolong sedang dengan persentase $55,37 \%$. Persentase tersebut merupakan yang paling tinggi dibandingkan dengan persentase kesulitan belajar pada indikator pembelajaran lainnya. Berdasarkan persentase tersebut dapat diketahui bahwa lebih dari setengah jumlah siswa seluruhnya mengalami kesulitan belajar pada indikator ini. Jumlah soal pada indikator ini adalah 3 soal yang tersebar pada aspek kognitif C4 (2 soal) dan C5 (1 soal). Pemilihan kata kerja operasional setiap aspek kognitif soal sudah sesuai dengan standar dan ketentuan yang mengharuskan siswa untuk mampu menganalisis dan mengevaluasi pengetahuan yang dimiliki sebelumnya. Namun berdasarkan hasil tes diketahui bahwa sebagian besar siswa gagal menjawab soal pada indikator pembelajaran ini dengan benar.

Aini (2017) dalam penelitiannya menyatakan bahwa penerapan LKS berbasis penemuan terbimbing dapat meningkatkan hasil belajar siswa pada materi Sistem Ekskresi Manusia. Dengan penerapan LKS berbasis penemuan terbimbing ini berdampak pada kemampuan siswa dalam pemahaman konsep. Namun keefektifan LKS berbasis penemuan terbimbing ini juga harus didukung dengan faktor lain seperti ketersediaan fasilitas sekolah, sumber informasi, dan kompetensi guru.

\section{Angket}

Angket yang digunakan dalam penelitian ini disusun berdasarkan materi Sistem Ekskresi Manusia. Angket ini dijadikan acuan dalam mengukur seberapa jauh kemampuan siswa merasa dirinya dapat mengetahui, mengerti, memahami, dan mendeskripsikan materi Sistem Ekskresi Manusia. Selain itu, angket kesulitan belajar siswa juga berisikan tentang sistem pembelajaran yang berlangsung pada materi Sistem Ekskresi Manusia. Pengisian angket dilakukan oleh 15 orang siswa tiap kelas yang memperoleh nilai tes hasil belajar dibawah KKM $(<75)$ dengan nilai terendah. Pada Tabel 4 diperoleh data dari hasil pengisian angket kesulitan belajar materi Sistem Ekskresi Manusia.

Berdasarkan Tabel 4, siswa kelas XI IPA SMA Swasta Teladan Medan mengalami kesulitan dalam mempelajari materi yang berkaitan dengan indikator (2) Struktur dan fungsi organ ginjal pada sistem ekskresi manusia dengan persentase $62,77 \%$ dan (3) Proses pembentukan urin, dengan persentase $62,77 \%$. Selain itu, melalui angket siswa juga menyatakan cukup mengalami hambatan dalam mempelajari materi Sistem Ekskresi Manusia pada indikator (1) Pengertian sistem ekskresi dan organnya dengan persentase 50,37\%, (5) Struktur dan fungsi organ paru-paru pada sistem ekskresi manusia dengan persentase $57,59 \%$, (4) Struktur dan fungsi organ hati pada sistem ekskresi manusia dengan persentase 48,33\%, (7) Kelainan/penyakit pada sistem ekskresi manusia dengan persentase $59,30 \%$, dan indikator (8) Sistem pembelajaran pada materi sistem ekskresi, dengan persentase $57,88 \%$. Sedangkan pada indikator (6) Struktur dan fungsi organ kulit pada sistem ekskresi manusia, 
melalui angket siswa menyatakan tidak mengalami hambatan dengan persentase 43,33\%. Pada Tabel 4 dapat dilihat bahwa ada tiga kategori yang menjadi hasil penilaian angket, yaitu tidak menghambat, cukup menghambat, dan menghambat.

Tabel 4. Distribusi Hasil Angket Kesulitan Belajar Siswa

\begin{tabular}{|c|c|c|c|c|}
\hline No & Indikator & No. Item & $\begin{array}{c}\text { Persentase } \\
\text { Indikator (\%) }\end{array}$ & Kategori \\
\hline 1 & $\begin{array}{l}\text { Pengertian sistem ekskresi dan } \\
\text { organnya }\end{array}$ & $1,2,3$ & 50,37 & $\begin{array}{c}\text { Cukup } \\
\text { Menghambat }\end{array}$ \\
\hline 2 & $\begin{array}{l}\text { Struktur dan fungsi organ ginjal pada } \\
\text { sistem ekskresi manusia }\end{array}$ & 5,15 & 62,77 & Menghambat \\
\hline 3 & Proses pembentukan urin & $\begin{array}{c}10,12,13,14,16 \\
17,21,25\end{array}$ & 62,77 & Menghambat \\
\hline 4 & $\begin{array}{l}\text { Struktur dan fungsi organ hati pada } \\
\text { sistem ekskresi manusia }\end{array}$ & 9,22 & 48,33 & $\begin{array}{l}\text { Cukup } \\
\text { Menghambat }\end{array}$ \\
\hline 5 & $\begin{array}{l}\text { Struktur dan fungsi organ paru-paru } \\
\text { pada sistem ekskresi manusia }\end{array}$ & $6,7,8$ & 57,59 & $\begin{array}{l}\text { Cukup } \\
\text { Menghambat }\end{array}$ \\
\hline 6 & $\begin{array}{l}\text { Struktur dan fungsi organ kulit pada } \\
\text { sistem ekskresi manusia }\end{array}$ & $4,11,18$ & 43,33 & $\begin{array}{c}\text { Tidak } \\
\text { Menghambat }\end{array}$ \\
\hline 7 & $\begin{array}{l}\text { Kelainan/penyakit pada sistem } \\
\text { ekskresi manusia. }\end{array}$ & $\begin{array}{l}19,20,23 \\
24\end{array}$ & 59,30 & $\begin{array}{l}\text { Cukup } \\
\text { Menghambat }\end{array}$ \\
\hline 8 & $\begin{array}{l}\text { Sistem pembelajaran pada materi } \\
\text { sistem ekskresi manusia. }\end{array}$ & $\begin{array}{l}26,27,28 \\
29,30\end{array}$ & 57,88 & $\begin{array}{c}\text { Cukup } \\
\text { Menghambat }\end{array}$ \\
\hline
\end{tabular}

Angket yang digunakan dalam penelitian ini adalah angket tertutup yang relatif mudah dalam pengumpulan data dari responden deangan jumlah yang besar. Data yang diperoleh dari pengisian angket adalah data yang dikategorikan sebagai data faktual. Angket yang disusun dengan baik dapat mengumpulkan informasi sesuai dengan hasil yang diinginkan oleh peneliti.

Angket yang diberikan kepada siswa digunakan untuk memperoleh informasi dari siswa tentang kesulitan belajar siswa pada materi sistem ekskresi manusia. Angket yang digunakan dalam penelitian ini terdiri dari tujuh indikator sebagai tinjauan materi seperti indikator (1) Pengertian sistem ekskresi dan organnya, (2) Struktur dan fungsi organ ginjal pada sistem ekskresi manusia, (3) Proses pembentukan urin, (4) Struktur dan fungsi organ hati pada sistem ekskresi manusia, (5) Struktur dan fungsi organ paru-paru pada sistem ekskresi manusia, (6) Struktur dan fungsi organ kulit pada sistem ekskresi manusia, dan (7) Kelainan/penyakit pada sistem ekskresi manusia, serta ditambah satu indikator sebagai tinjauan bagaimana proses pembelajaran yang berlangsung pada materi Sistem Ekskresi Manusia yaitu indikator (8) Sistem pembelajaran pada materi sistem ekskresi. Indikator inilah yang menjadi dasar bagi peneliti dalam menyusun pertanyaan kesulitan belajar pada materi Sistem Ekskresi Manusia.

Berdasarkan hasil penelitian diperoleh data yang menunjukkan bahwa 2 terdapat 2 indikator yang termasuk ke dalam kategori menghambat proses belajar pada materi Sistem Ekskresi Manusia, yaitu indikator (2) dengan persentase $62,77 \%$ dan indikator (3) dengan persentase $62,77 \%$. Jumlah pernyataan pada masing-masing indikator adalah 2 pernyataan pada indikator (2) dan 8 pernyataan pada indikator (3). Untuk mengatasi kesulitan belajar siswa pada indikator pembelajaran ini, dibutuhkan solusi yang dapat membantu siswa dalam memahami indikator yang tergolong rumit dan abstrak. Salah satu solusi yang dapat ditawarkan adalah Virtual Laboratory. Adi, dkk (2016) dalam penelitiannya menyatakan bahwa penggunaan Virtual Laboratory mampu meningkatkan motivasi belajar siswa yang berpengaruh baik terhadap hasil belajar siswa. Hal ini dikarenakan keberadaan Virtual Laboratory mampu menarik minat siswa, mempermudah dalam penyediaan alat dan bahan karena sudah tersedia secara virtual, serta memberikan 
kebebasan siswa dalam melakukan praktikum karena dapat mengulangi proses percobaan.

Selain itu, melalui angket siswa juga menyatakan cukup mengalami hambatan dalam mempelajari materi Sistem Ekskresi Manusia pada indikator (1) dengan persentase 50,37\%, (5) dengan persentase $57,59 \%$, (4) dengan persentase $48,33 \%$, dan (7) dengan persentase 59,30\%. Sedangkan pada indikator (6) melalui angket siswa menyatakan tidak mengalami hambatan dengan persentase $43,33 \%$. Kesulitan belajar yang dialami oleh siswa mungkin dikarenakan sistem pembelajaran pada materi sistem ekskresi manusia yang belum terlaksana dengan baik. Seperti data yang diperoleh dari hasil pengisian angket oleh siswa diketahui bahwa indikator (8) dengan persentase 57,88\%. Pada pernyataan nomor 27 mengenai ada tidaknya praktikum yang dilakukan dalam mempelajari materi sistem ekskresi, diperoleh persentase sebesar 79,4\% yang berarti hal tersebut menghambat proses pembelajaran materi Sistem Ekskresi Manusia. Sementara itu pada pernyataan nomor 30 mengenai pemahaman siswa tentang materi Sistem Ekskresi Manusia ketiga guru memberikan sumber belajar lain, diperoleh persentase sebesar $62,8 \%$ yang berarti hal tersebut menghambat proses pembelajaran materi Sistem Ekskresi manusia.

\section{Hubungan Tes Hasil Belajar dan Hasil Angket Kesulitan Belajar Siswa}

Berdasarkan perolehan tes hasil belajar dan hasil angket kesulitan belajar yang diisi oleh siswa, diketahui bahwa antara tes hasil belajar dan angket saling berhubungan. Dari perolehan tes hasil belajar siswa pada indikator (2) Mengidentifikasi struktur dan fungsi ginjal sebagai organ ekskresi manusia dengan persentase $48,15 \%$ dan (3) Mendeskripsikan struktur nefron dan menjelaskan proses pembentukan urin pada manusia dengan persentase $54,32 \%$. Kedua indikator tesebut tergolong pada kategori tingkat kesulitan sedang. $\mathrm{Hal}$ ini sesuai dengan hasil angket yang diperoleh pada indikator (2) Struktur dan fungsi organ ginjal pada sistem ekskresi manusia dan (3) Proses pembentukan urin, diketahui siswa mengaku mengalami kesulitan dalam memahami sub materi tersebut dengan persentase $67,78 \%$ untuk masingmasing indikator yang tergolong kategori menghambat.
Pada indikator tes hasil belajar siswa (7) Menentukan kelainan atau penyakit pada organ ekskresi pada manusia, tergolong kaegori tingkat kesulitan tinggi dengan persentase $66,67 \%$. Dan pada angket dengan indikator yang sama, yaitu (7) Kelainan/penyakit pada sistem ekskresi manusia diperoleh persentase 59,30\% dengan kategori cukup menghambat. Kedua hasil tersebut saling berhubungan karena berdasarkan tes hasil belajar terdapat lebih dari setengah siswa mengalami kesulitan dalam menjawab tes yang berhubungan dengan indikator tersebut. Begitu juga dengan hasil angket, lebih dari setengah siswa mengaku mengalami kesulitan dalam memahami indikator yang sama.

Hal yang sama juga dapat dilihat pada indikator tes hasil belajar siswa (1) Menyebutkan pengertian sistem ekskresi serta organnya, (4) Mengidentifikasi struktur dan fungsi hati sebagai organ ekskresi manusia, dan (5) Mengidentifikasi struktur dan fungsi paru-paru sebagai organ ekskresi manusia. Dengan persentase masingmasing yaitu $54,32 \%$, 47,33\%, dan $58,27 \%$, yang tergolong kategori tingkat kesulitan sedang. Dan pada angket dengan indikator yang sama, yaitu (1) Pengertian sistem ekskresi dan organnya, (4) Struktur dan fungsi organ hati pada sistem ekskresi manusia, dan (5) Struktur dan fungsi organ paruparu pada sistem ekskresi manusia diperoleh persentase masing-masing indikator 50,37\%, $48,33 \%$, dan 57,59\%. Ketiga indikator tersebut tergolong kategori cukup menghambat.

Pada indikator tes hasil belajar siswa (6) Mengidentifikasi struktur dan fungsi kulit sebagai organ ekskresi manusia, tergolong kategori tingkat kesulitan sedang dengan persentase 57,04\%. Sementara hasil angket pada indikator yang sama (6) Struktur dan fungsi organ kulit pada sistem ekskresi manusia, tergolong tidak menghambat dengan persentase 43,33\%. Adanya ketidaksesuaian antara perolehan tes hasil belajar dan angket menyebabkan keraguan akan reliabilitas angket terhadap hasil tes. Instrumen penelitian yang di uji validitas dan reliabilitas oleh validator ahli dan siswa hanya instrumen soal, sedangkan instrumen angket hanya dilakukan uji validitas oleh validator ahli. Sebaiknya uji validitas instrumen angket juga dilakukan kepada siswa. Penggunaan jenis angket menjadi angket semi- 
tertutup juga bisa dilakukan agar siswa menjadi lebih fokus dan lebih jujur dalam menjawab angket karena membutuhkan alasan dari setiap jawabannya. Dengan cara ini, diharapkan jawaban yang diperoleh dari siswa menjadi lebih murni dan spesifik karena disertai alasan yang mendukung.

\section{KESIMPULAN}

Berdasarkan hasil penelitian dan analisis data, maka dapat disimpulkan sebagai berikut (1) Tingkat kesulitan belajar siswa pada materi Sistem Ekskresi Manusia di kelas XI IPA SMA Swasta Teladan Medan Tahun Pembelajaran 2017/2018 berdasarkan aspek kognitif dari tertinggi ke terendah adalah pada tingkat C5 (Evaluasi) dengan persentase 70,78\%, C4 (Analisis) dengan persentase 59,61\%, C6 (Sintesis) dengan persentase 59,26\%, C1 (Pengetahuan) dengan persentase 56,38\%, C2 (Pemahaman) dengan persentase 50,31\%, dan C3 (Aplikasi) dengan persentase 48,64\%; (2) Tingkat kesulitan belajar siswa pada materi Sistem Ekskresi Manusia di kelas XI IPA SMA Swasta Teladan Medan Tahun Pembelajaran 2017/2018 berdasarkan aspek indikator pembelajaran dari tertinggi ke terendah adalah pada indikator (7) sebesar 66,67\%, indikator (5) sebesar 58,27\%, indikator (6) sebesar $57,04 \%$, indikator (1) dan (3) sebesar 54,32\%, indikator (2) sebesar 48,15\%, serta indikator (4) sebesar 47,33\%; (3)Sub materi penyebab kesulitan belajar siswa pada materi Sistem Ekskresi Manusia di kelas XI IPA SMA Swasta Teladan Medan Tahun Pembelajaran 2017/2018 yang paling dominan adalah indikator (2) sebesar $62,77 \%$ dan indikator (3) sebesar $62,77 \%$ yang tergolong kategori menghambat. Sedangkan indikator (1), (4), (5), (7), dan (8) tergolong kategori cukup menghambat. Dan indikator (6) tergolong kategori tidak menghambat dengan persentase $43,33 \%$.

\section{DAFTAR PUSTAKA}

Adi, W. C., Suratno, S., \& Iqbal, M. (2016). Pengembangan Virtual Laboratory Sistem Ekskresi dalam Meningkatkan Motivasi Belajar Siswa SMA. Jurnal Pendidikan Sains, 4(4), 130-136.

Aini, N. (2017). Penerapan lembar kegiatan siswa berbasis penemuan terbimbing materi sistem ekskresi manusia untuk meningkatkan hasil belajar siswa kelas XI
SMA. BioEdu, 6(2).

Baharuddin, H. dan Esa N. W. (2015). Teori Belajar dan Pembelajaran. Penerbit Ar- Ruzz Media, Yogyakarta.

Cimer, A. (2012). What makes biology learning difficult and effective: Students' views. Educational Research and Reviews, 7(3), 6171.

Hasibuan, S. R. (2013). Faktor-faktor Penyebab Kesulitan Belajar Biologi Pada Siswa Di Kelas XI IPA di SMA Negeri 2 Perbaungan Tahun Pelajaran 2012/2013 (Undergraduated thesis, UNIMED).

Kaberi, K. (2016). Meningkatkan Hasil Belajar Materi Sistem Ekskresi pada Manusia Menggunakan Pembelajaran Inkuiri Terbimbing Siswa Kelas XI IPA 1 SMA Negeri 6 Banjarmasin Tahun Pelajaran 2013/2014. Wahana-Bio: Jurnal Biologi dan Pembelajarannya, 15(1).

Kwartolo, Y. (2012). Multiple intelligences dan implementasinya dalam taksonomi Bloom. Jurnal Pendidikan Penabur, 18(11), 66-77. Ristiyani, E., \& Bahriah, E. S. (2016). Analisis kesulitan belajar kimia siswa di SMAN X Kota Tangerang Selatan. Jurnal Penelitian dan Pembelajaran IPA, 2(1), 18-29. 